\title{
SZIMBOLIKUS POLITIKAI FORDULATOK ÉS TÉRBELI MINTÁZATAIK: KÖZTERÜLETEK ÁTNEVEZÉSE BUDAPEST I. ÉS V. KERÜLETÉBEN
}

\author{
BAROCH CSABA \\ SYMBOLIC POLITICAL TURNS AND THEIR SPATIAL PATTERNS: \\ RENAMING PUBLIC SPACES IN THE $1^{\text {ST }}$ AND $5^{\text {TH }}$ DISTRICTS OF BUDAPEST
}

\begin{abstract}
The (re)naming of public spaces has become a central feature of one of the most known spatial references in everyday urban life. These names help in spatial orientation and administration. In addition, they are accumulations of collective memory and part of a "propaganda machine" of current (political) power. In this study I show that the network of public places and spaces are not only flow-zones, but also social products and, ultimately, a collection of symbolic space-elements which influence and shape society. In my opinion, this article's case studies, which are the $1^{\text {st }}$ and $5^{\text {th }}$ districts of Budapest, are perfect examples of a certain political phenomenon that occurs when a series of political acts and countermeasures are manifested as spatial patterns and legible city-texts. Adopting a critical view, this paper analyses the thematic spatial patterns, texts, and changes of street names in Budapest's two core neighbourhoods by exploring the underlying political-power relationships and by questioning and contesting their appropriateness and oppression.
\end{abstract}

Keywords: public space, critical urban geography, place name, power, politics of memory

\section{Bevezetés}

Az utcák, terek nevei jól látható feliratként mindennapjaink részévé váltak. Segítik a tájékozódást, térbeli hivatkozási pontot nyújtanak, de egyúttal a kollektív emlékezetet tároló fogalmak és politikai eszközök is (AUGÉ, M. 1995 [1992]). Elsődleges funkciójuk a városon belüli eligazítás, emellett kulturális, politikai és történeti reprezentációk. Tanulmányomban Budapest I.és V. kerületének köztérnév-hálózatán keresztül arra szeretnék rámutatni, hogy a közterületek nem puszta áramlási csatornák. Rögzített helyek is a térben, kölcsönkapcsolatban állva a térhasználókkal és a városszövettel, valamint transzgresszív, dinamikus társadalmi képzódmények, melyeknek nem csak fizikai paramétereik, hanem szimbolikus tulajdonságaik is változnak.

Legfőképpen arra szeretnék választ találni, hogy a közterületnevek összefüggéseiből keletkezhetnek-e térbeli mintázatok, illetve hogy egy adott átnevezési hullám esetében ezek milyen mértékig változnak. Fő vizsgálati területnek szánom az egymást magyarázó utcanévcsoportok megjelenéseit, felszíni kibukkanásukat. Vizsgálódási szempontom továbbá, hogy egy adott átnevezési hullámhoz kapcsolódó kurzusváltás miképp bánik a város múltjával, jelenével.

Tanulmányom szemlélete el kíván rugaszkodni a lexikonszerú, tipizáló kutatásoktól és a helytörténeti monográfiáktól. Az említett leíró munkák rendkívül fontos források, melyek jelen szöveg kiindulópontját is képezik, ahogy az a későbbi névadástörténeti és módszertani bemutatásban is olvasható (Budapestről lásd SCHMALL L. 1906; RÁDAY M. 2013; külföldről például KAUPS, M. 1966). Azonban a két kerületi esettanulmány és az ezeket követô komparatív fejezet ki kíván lépni a városi szimbolikus térelemek szerepének passzív meghatározásából. A nemzetközi kritikai toponímia (elsősorban AzARYAHU, M. 1996, 2011), valamint ERŐSS Á. (2018) a köztér szimbolikus (el)birtoklásáról szóló mun- 
kássága segítségével a mindenkori hatalom térbeli megnyilvánulásait szeretném bemutatni, egy olyan szimbolikus köztéri platformon keresztül, melynek narrációja régóta a politikai elit kiváltsága, ugyanakkor társadalmi térben való kiterjedtsége és megfoghatósága miatt a mindennapi élet és az ellenállás közege is lehetne.

\section{Elméleti kontextualizálás térben és időben}

A köztérnevek alapvetően tükrözhetik jelen vagy múlt társadalmi sajátosságait, például a lakosok etnikai hovatartozását, családok vagy felekezetek birtokát. Reflektálhatnak környezetük gazdasági folyamataira, idomulhatnak a természet vagy az ember formálta tájhoz, segítve a földrajzi térben való tájékozódást a településen belül, és hozzávetôlegesen annak határain túl (STOREY, D. 2011). A 19. század vége óta azonban a tér, a hely, a név és annak denotatív vagy konnotativ jelentése eltávolodhat egymástól, a jelek, jelentések és olvasatok a különbözó tértermelési síkok mentén széttarthatnak (BARTHES, R. 1967; LEFEBVRE, H. 1991 [1974]; BнABHA, H. K. 1994). A spontán vagy motivált névadás jellemző, a látottakat egyszerű szöveggé formáló gyakorlatát követően a közterek sok esetben történelmi személyeknek, eseményeknek állítanak emléket (AUGÉ, M. 1995 [1992]; BIRK Z. 1996; T. SOMOGYI M. 2005; N. KovÁCs T. 2007). A város egészéhez vagy akár az államhoz kötődő kulturális vagy politikai indíttatásból adott köztérnév pedig már nem feltétlen lesz helyhez vagy helyi cselekvőhöz kötött. A közös emlékezet felülről legitimált elemei inkább az adott földrajzi tér központiságával, láthatóságával, szerkezeti helyének minőségével veszik fel a kapcsolatot. Ez pedig eltávolítja egymástól a teret-helyet, a hivatkozó nevet és a térhasználókat, akik ezt a hivatkozást alkalmazzák (AzARYAHU, M. 1996; FouCAult, M. 2000 [1967]). A helynevek így már nem leképződések, hanem teret és használóit alakító tényezők, amik mentén megfigyelhetô akár a lokalitások és a nemzeti narratíva oppozíciója is (GYÁNI G. 2016).

A névadás eredendően kategorizáló gondolkodásmód, mely helyek vagy dolgok különbözőségükben való létét hangsúlyozza. Ennek értelmében a névadás hatalmi diszpozíció, a meghódítás szimbóluma (DERRIDA, J. 1997 [1967]; AZARYAHU, M. 1996). A városkép vagy a városszövet szimbolikus elemeinek megváltoztatása mindig függött a hatalom módszerétôl, hogy közvetett (diffúz) vagy közvetlen irányítás magasodik feléjük. Változó mértékben, de a központi hatalom mindkét esetnél presszionálta a helyieket a köztérnevek kialakítására vagy megváltoztatására. Ennek oka a nyugati politikai rendszerek legfőbb célja: adminisztráció és kontroll (FouCAULT, M. 1990 [1975]).

A különböző dekolonizációs időszakokban (NoRA,P. 2007), a felszabaduló gyarmatoknál és a kurzus- és rendszerváltásokat megélő centrumoknál, félperifériáknál három átnevezési stratégiát lehet megfigyelni. Sok ország eltörli az előző rendszer köztéri emlékezetét és úgynevezett patrióta toponímiával helyettesíti, de számos esetben megmaradhatnak az előző politikai rendszert képviselő utcanevek (KADMON, N. 2004). A meghagyás egyfajta taktikája jelezheti az exgyarmatok kulturális elidegenedését: az adott társadalom elszakad ősi kultúrájától, pontosabban a közterekben megjelenő új (kolonialista) szereplők felülírják azt. A politikai (rendszer)váltás esetén a részleges meghagyás/átírás adhatja a város szimbolikus szövetének kontinuitását, szinkronicitását és a történeti sokféleség a szimbolikus térben vett rizomatikus szerkezetét (JunG, C. G. 1972; NoRA, P. 1999; Deleuze, G.-GuATTARI, F. 2005 [1987]). A korábbi fennhatóság szelektív törlése mellett praktikai jelentőséggel kétnyelvú nomenklatúra is létrejöhet (AZARYAHU, M. 2011). Ez a (volt) gyarmati sorsú területeken a helyi dialektus és a gyarmatosító, közvetítôként funkcionáló nyelv együttes megjelenését mutatja (YEOH, B. 1992). Egyes etnokulturálisan összetett, több domináns nyelvû csoportot tartalmazó régióban és városban szintén kettô, ám kevésbé 
eltérő funkciójú nyelvek szerepelhetnek az utcatáblákon (BAUKO J. 2015; ERŐss Á. 2016). Bizonyos latintól eltérő írásképeknél pedig egyazon nyelvnek két formája is megjelenhet, főleg a turisták által látogatott negyedekben (BAROCH C.-BERKI M. 2019). A kettós utcanevek átmeneti megjelenése pedig tanulmányom fő témájául is szolgáló köztér-átnevezések gyakorlatánál is előfordul. Jogszabályi kerettől függóen a tájékozódást és adminisztrációt elősegítve az átnevezés közvetlen időbeli (liminális) környezetében egyszerre jelen lehet a közterület régi és új neve. Hivatalos formában a régebbi név áthúzásával, informálisan pedig a két megnevezés eltéró stílusú megjelenítésével. Ezen sokféleség jól mutatja, hogy a de-és rekolonizáció a városi társadalom és politika különbözó rétegeiben eltéró mértékben és idôpontban jelenhet meg (NORA, P. 2007).

Nyugat-Európában kétfajta átnevezési trend figyelhetô meg. A párizsi gyökerú politikai szimbolizmus városszövete folyamatosan, organikusan változik. Ez időről időre megbontja a városszövetet, de több narratíva megjelenítésére is képes (Augé, M. 1995 [1992]; AzARYAHU, M. 1996). London példája pedig a névismétlődésekkel járó köztérnévi kontinuitást helyezi előtérbe, így az utcanevek alaki változása helyett konnotációik formálódnak (BARTHES, R. 1967; PÓTó J. 2012). A posztszocialista országokban jellemzóbb bizonyos történelmi időszakok teljes törlése (PALONEN, E. 2008). Legtöbb esetben az átkeresztelések már komolyabb válságjelenségek idején megkezdődnek: például a sztálinizmus szimbolikus hazai leépülése a hatvanas években (PALONEN, E. 2008). Így Köztes-Európában felvethető tény, hogy a nagyobb toponimikus változások egy grandiózus politikai fordulathoz, forradalmi szituációhoz köthetők. A közelmúltból és a jelenből is ismert átkeresztelési hullám viszont a történelem egy elhúzódó, liminális szakaszát jelzi (AzARYAHU, M. 1996).

A Duna két oldalának városmagjaiban csoportosul kulturális és politikai központi elemek sokasága, melyek a nevezéktan legdinamikusabb alakítói. A várost használók kortól, nemtől, osztálytól, identitástól függetlenül részt vesznek ezen központi kerületek alakításában és ezek rájuk is visszahatnak. Igaz, a kiszolgáltatottabb rétegek inkább elszenvedői a centrum közegének, míg a mindenkori hatalmi elit és szövetségesei közvetlen, erôteljes ráhatással bírnak. A Várkerület és Belváros-Lipótváros (részletezve lásd: 1. ábra) tehát

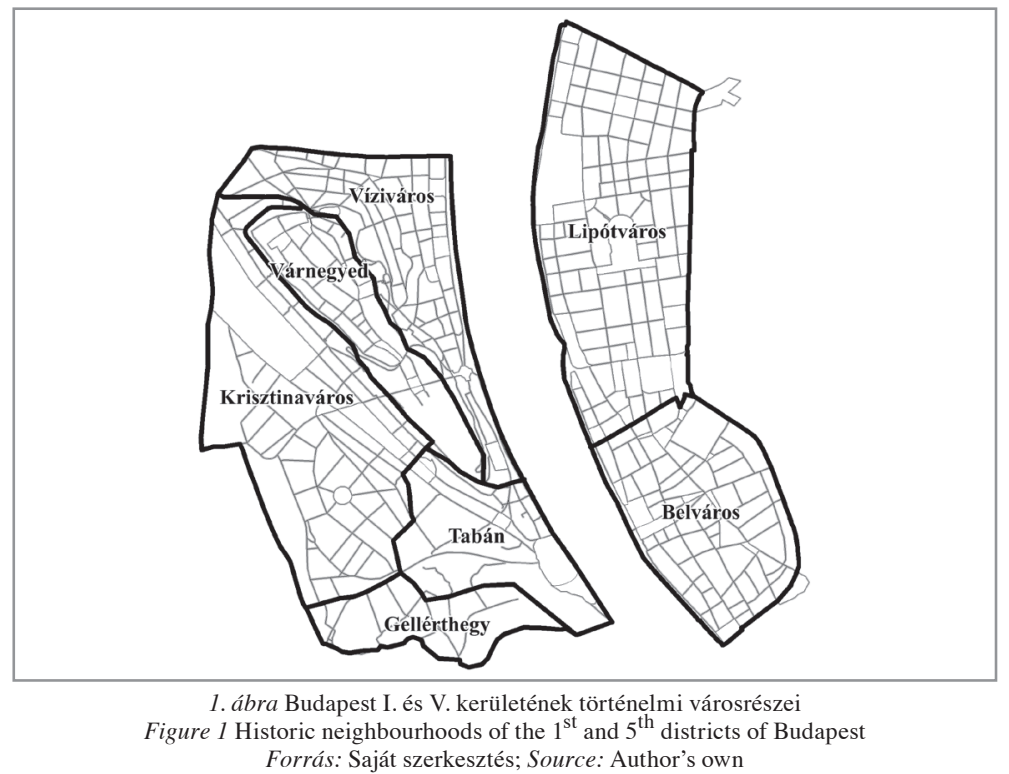


Budapest tipikus kulturális küzdőterei, ahol a köztérelnevezések össztársadalmi produktumnak tûnnek, miközben teljesen áthatja őket az aktuális hatalmi kontroll, többnyire elhallgatva vagy névlegessé téve a helyi társadalom a köztérelnevezési diskurzusban való részvételét (Rose-Redwood, R.-ALdERMAN, D.-AzARYAHU, M. 2009).

\section{Törések, korszakok, szokások: utcanévadás Budapesten}

A városszövetet egy palimpszeszthez hasonlítva: a helynevek textúrája több idősík maradványát őrzi (Rose-Redwood, R.-Alderman, D.-AzARYAHU, M. 2009). Budapest történelmi, hatalmi kereteihez ragaszkodva ezen városi palimpszeszten belül T. SoMOGY M. (2005) hét, PÓTó J. (2012) öt, RÁDAY M. (2013) hat korszakban állapodik meg.

Az utcaelnevezéseink hajnalát a török hódoltság előtti és alatti történelmi időszakokra lehet osztani. Egységesen hivatkozhatunk mindkettőre a középkori címkével (РóTó J. 2012). Kortörténetileg ugyan hibás megfogalmazás, de a névadási szokásokat tekintve homogén időszak. Technikailag ekkoriban az alapvető, köznévi megkülönböztetéshez szükséges spontán, motivált elnevezések domináltak, közvetett-ideiglenes hatalmuk okán észrevehetetlen török lenyomattal (BIRK Z. 1996; T. SOMOGYı M. 2005).

A következő időszakot mindhárom szerző a török kiűzésétől Budapest megszületéséig veszi. Ekkoriban a hivatalos nyelv a német volt, így a magyar lakosság a német nevek magyarra lefordított verzióját alkalmazta (T. SomOGYI M. 2005), de az 1696-os telekkönyvrendezéssel csak a német elnevezések kerültek nyilvántartásba (RÁDAY M. 2013).

Az I. és V. kerület elsố névváltozási fordulata a németről való átfordítás időszaka, illetve a városegyesítéssel az utcanévjegyzék rendezése volt. Ez sok esetben szemantikai ferdítéssel járt, kiváltképp a német családnevek esetén (Unger-Magyar vagy Spiegel-Tüköry). Az elnevezések-átnevezések feladatköre az 1870-ben alapított Fövárosi Közmunkák Tanácsának feladata lett. Fő rendezőelvük a névismétlések mellőzése volt. A szokványos utcaneveket (Iskola, Templom vagy Kaszárnya) rokon kifejezésekre cserélték (Tanoda, Torony, Laktanya) (RÁDAY M. 2013). Összességében a magyar nyelv bekerült a városi tájékozódás hivatalos koordinátarendszerébe, a Fővárosi Közmunkák Tanácsával pedig általánossá vált a közterek névadásának intézményesült, a mindenkori államhatalom által szabályozott jogi aktusa.

A világháborúk közeledtével számos reprezentatív köztér a szövetséges hatalmak propagandafelïletévé vált. Így kapott utcát vagy teret Mehmed szultán, Ferdinánd bolgár cár, Mussolini, Rothermere, Hitler, akik szövetséges hatalmak vezetôi voltak és/vagy támogatták a hazai irredentizmust (РóTó J. 2012). A nacionalizmus stratégiai erósítésével az irredenta utcanevek az első bécsi döntést követően határainkon túlra terjedtek (ERőss Á. 2016), és ekkoriban keletkeznek fóvárosunkban az elszakitott országrészeket idézó utcanévbokrok.

1948-ra az államszocialista rendszer begyűrűzésével a köztérelnevezések feleadatköre a Fővárosi Tanács kezébe kerül. Az extenzív szocialista szimbolizmus és propaganda mellett hasonló munkát folytatott, mint elődje, csak más ideológiai síkon. Betiltották az élő személyekről való utcaelnevezést, viszont a potenciális jelöltekről rögtön haláluk után kiállíthatnak utcatáblát. Ezen kívül a névegyezés kérdését a kerületre korlátozták, megteremtve ezzel a lehetőséget, hogy összes városrész központi területén kialakítsák a hazai és internacionális munkásmozgalom ihlette városszöveget (РóTó J. 2012; PALONEN, E. 2008).

A nyolcvanas években induló posztszocialista átalakulás (PALONEN, E. 2008; RÁDAY M. 2013) a Fővárosi Tanács 1990-es megszűnésével átadta a közterek elnevezésével kapcsolatos döntéshozatalt az önkormányzatoknak. A recens állapothoz célszerú a hatályban lévő a közterület- és városrésznevek megállapításáról, azok jelöléséről, valamint a házszám-meg- 
állapítás szabályáról szóló 94/2012. (XII. 27.) Fővárosi Közgyưlés rendeletet áttekinteni (utolsó módosítása 2018. november 14.). Közterületről akkor beszélünk, ha az köszhasználatban van, birtokosa az állam vagy adott önkormányzat. Hivatkozásukra érvényes, hogy egyetlen közterület sem maradhat névtelenül, a nevek előtagból és utótagokból állhatnak, a dátumok, számnevek, ismétlődések az új elnevezéseknél kerülendők. Élő személy nevét továbbra sem viselheti közterület. A Közgyuulés által díszpolgárrá kinevezettekről viszont automatikusan lehet közterületet átnevezni, pedig ezt nem előzi meg semmilyen társadalmi igény - így a cím előnyt élvez mind a korábbi elnevezésekkel, mind a sokféleséggel, tradícióval, közigénnyel szemben. Az átnevezések alól kivétel csupán egy tizenöt évnél nem régebbi név és a helytörténeti érték kel bíró védett (nem személyi kötődésû) köztérnév lehet.

\section{Adatbázisépítés, forráshasználat}

A mindenkori utcaneveket és a hozzájuk kapcsolható dátumokat, történelmi tényeket a RÁDAY M. (2013) szerkesztette Budapesti utcanevek A-Z címú lexikon alapján használom. A feldolgozott adattár pedig RÁDAY M. (2013) és Mészáros György érdeme. A lexikont felhasználva kiírtam a kerületek számát, a történelmi városrészek nevét, a jelenleg használatos megnevezést, utóbbi beiktatásának dátumát. Melléjük rögzítettem az egyes utcák és terek korábbi részleges vagy teljes elnevezését. Ezek hatályosságának időintervallumát is jeleztem. A hatodik tényező a különböző időpontban érvényes nevek rövid jelentésmagyarázata volt. A kerületi elemzések az említett perspektívák mentén lettek kialakítva, valamint a tematikus térképek attribútumtábláit is a fenti adatok alapján állítottam össze. Az adattáblák rendezőelvénél kiinduló feltételezésem volt, hogy a történelmi városrész kategória autonóm egységként nyilvánulhat meg (elhelyezkedésüket lásd: 1.ábra). A városrészeken belül próbáltam a jelenlegi és a valaha volt nevek alapján különböző térbeli-tematikus mintázatokat felfedni, így számos példája akadt, hogy összefüggéseket több idősík egyszerre kezelése miatt lehetett feltárni (RoSE-REDWOOD, R.-ALDERMAN D. - AzARYAHU, M. 2009). Az egyes neveknél a jelentésükön túl fontosnak tekintetettem korábbi elnevezésekkel való kapcsolatukat, környezetükre való reflektálásukat és a szemiotikai hálóban elfoglalt szerepüket, illetve hogy a különböző rendszerek mennyire érezték fontosnak, hogy saját képükre formálják őket (AZARYAHU, M. 1996; ERŐss Á. 2016, 2018).

\section{A Várkerület szimbolikájának visszaszorulása}

Az I. kerület neveinek történetét nagyban befolyásolták a közterületek lefutásainak változásai, illetve a tabáni és krisztinavárosi területrendezési projektek. Ennek eredményeként számos középkori és újkori utcanév eltűnt, néhány pedig tabáni környezetéből kiemelve, egy közeli régióba került át. Az 1930-as években a Tabán rendezetlenségére hivatkozva lebontották a szerb telepesek által alapított sûrű beépítésú városrész nagyobb hányadát, azonban az új városépítészeti terv a világháború következtében sosem valósult meg. A Ráday-féle Budapesti utcanevek A-Z lexikon alapján feldolgozott hetvenkettő helyi köztérnévból hozzávetőlegesen tíz maradt meg, köztük a ma már csak névleges Hadnagy utcával (RÁDAY M. 2013). A Gellérthegyen családi névbokrok mellett a természeti környezetre utaló utcaneveket találunk, melyek a mintát folytatva a XI. kerületben is jellem-

zőek (Alsóhegy, Kelenhegyi, Szirtes). Mivel ez sosem számított tömegek által használt, reprezentatív köztérnek, a hatalmi változások és érdekek csak kevés esetben bolygatták (2.ábra). Hasonlóan konkrét helyzetéhez kötődő Belső-Krisztinaváros nevezéktana. Igazán 
jellegzetes minták ugyan nem alakultak ki, de jól kivehető a szoros kapcsolat a Várral (Lovas út, Lovarda utca). A Fővárosi Közmunkák Tanácsa által adományozott Logodi utca név pedig egy térben és időben is navigáló, egyedülálló emlék lett (NoRA, P. 1999). Logod még Krisztinaváros születése, sốt a török kor előtti falu volt a Rókus-hegyen. Ennek irányába és a múltba terel a mai utca futása. Továbbá Krisztinavárosban is megfigyelhetô, hogy kisebb utcának minősülő közterületek megmaradtak „út-i” rangban (Lovas út, Palota út). Ennek oka történeti jelentőségükben keresendő, de jól reflektál a német névadás emlékére, ahogy az sok budai utcánál észlelhető (McDAVID, R. I. 1958).

A Vár és környékének tematikájáról általában elmondható, hogy a világháborús vagy szocialista propaganda kis mértékben volt rá hatással (2. ábra). A falakon belül, ha nem is egyenesen középkori eredetú, de annak hangulatát idéző kis köznévi csoportot találhatunk (Balta, Kard, Dárda, Lant). A környék korábban is egységesen viselkedett: ott élő nemzetiségeket, szerzeteseket, mesterségeket, fogadókat jelzett. A legérdekesebb változások azonban mégis a szocialista éra alatt történtek. A Várnegyed Budapestnek egy olyan hatványozottan szimbolikus területe, amivel a létező szocializmus sehogy nem tudott azonosulni. Már csak épített környezete miatt képtelenség egy „year zero” típusú utcanévi tisztogatást véghezvinni (CZEPCZYŃSKI, M. 2008). Így a legfóbb cél nem a pártemberek és élmunkások láthatóvá tétele volt - hiszen azok összeférhetetlenek lettek volna a nemesi-úri világ szimbólumaival - hanem az egyházi jelképek eltüntetése. A Várban ennek eredménye a Hess András tér, a Petermann bíró utca, a Móra Ferenc utca; Vízivárosban pedig az

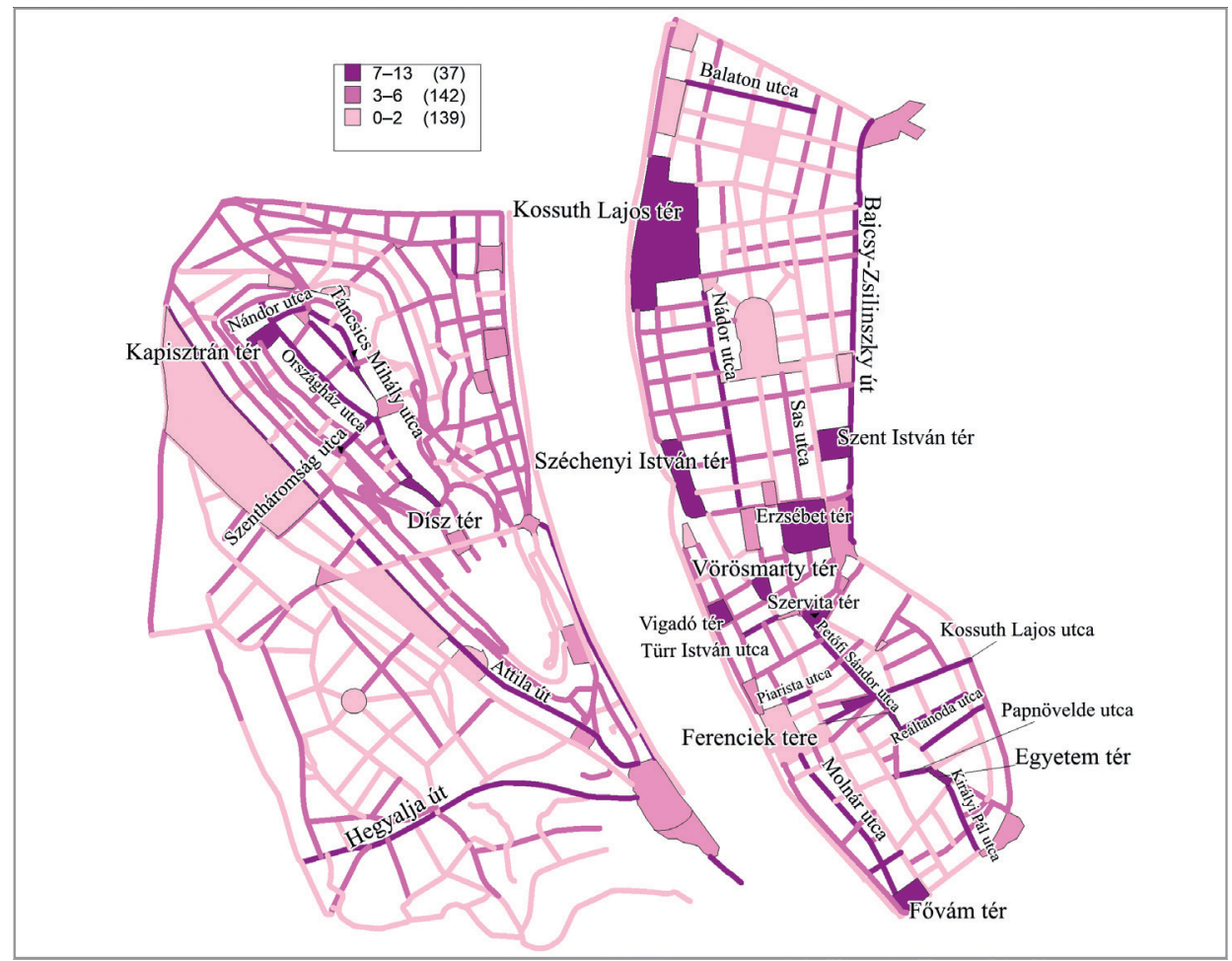

2. ábra Az I. és az V. kerület köztérátnevezési intenzitásának összehasonlítása az átnevezések száma alapján Figure 2 Renaming intensity of public spaces: comparison of the $1^{\text {st }}$ and $5^{\text {th }}$ disctricts' cases

Forrás: Saját szerkesztés RÁDAY M.-MÉsZÁRos G. 2013 alapján; Source: Author's own based on RÁDAY M.-MÉSZÁROS G. 2013 
Aranyhal utca, a Hunyadi László lépcső, a Halász lépcső vagy a Farkas bíró utca. Korábbi neveik minden tekintetben a keresztény egyházhoz kötődtek (kivétel a Móra Ferenc utca elődjeként jegyzett Casinó utcát, ami inkább a „darutollas” burzsoázia szimbóluma, illetve Petermann előtt a Nándor név elsősorban a monarchia és másodsorban a kereszténység jelképe). Ám új neveik nem a tisztogatást, hanem a magyar történelem egy másik - antiklerikális - szálát képviselik, illetve képviselték. A rendszerváltás után történt változások ugyanis némelyiküket visszaalakítják a katolicizmushoz kapcsolódó névre. A 2011-es Nándor utcává való visszakeresztelés több szempontból is problémás. Egyrészt a név jelentése kicsúszott a szemiotikai keretből, ugyanis a Ferdinánd laktanya vagy Nándor bástya eltûnése megmagyarázhatatlanná teszi a honosított keresztnevet. Továbbá könnyen keverhető az utcanevezéktanban használatos „,nádor” kifejezéssel (PóTó J. 2012). Ráadásul az utca párhuzamosan fut az Anjou bástyával, így egy érdekes történelmi oppozíció, küzdőtér szerepelhetett a városszövetben, a népakartért kiálló Petermann és a külföldi uralkodóház között (Rose-Redwood, R.-Alderman D.-AzARYAHU, M. 2009). Ebből is látszik, hogy az aktuális hatalom mindig történelemszemléletet egységesít (AZARYAHU, M. 1996). Bár a vallásosság mára talán kevésbé szempont az I. kerület mindennapjaiban vagy megélt terében, a rendszerváltás utáni jobboldali politikai erők előszeretettel nyúltak a nyugati kereszténység bástyájának retorikai fogásához. A várvédő harcokkal és katolikus hegemóniával szemben a vízivárosi rakpart egy későbbi megszállás és háború témakörében a pacifizmust és a civil vagy egyházi segítséget képviseli (Angelo Rotta, Sztehlo Gábor, Friedrich Born).

\section{Belváros-Lipótváros köztérnév-hálózata mint térbeli hatalmi allegória}

Belváros-Lipótváros utcanevei még a mai napig is intenzíven változhatnak (3.ábra). Az I. kerülethez képest az V. sokkal inkább Budapest politikai erőterének gócpontja, így az átnevezési hullámok is még nagyobb elánnal érintették/érintik. Amellett, hogy már a közterületek kiválogatásakor megfigyelhetô volt sok egyértelmúen egybefüggő mintázat, a névtörténetek felfejtésével újabbakra akadtam. Ezek letúnt korok és környezetek tematikái, melyekből a mai felszínen csak egy-egy hírmondó maradt. Egészen a kezdeteket képviselheti néhány kisebb közterület. A Bástya utca és a Kecskeméti utca jelentéstartalma korábban az egész környék utcaneveinek meghatározó eleme volt, mára azonban csak ezekben sejthetjük a déli városfal emlékét, ahogy a meghatározó kereskedelmi-adózási funkciók is mindössze a Só, Harmincad és Mérleg utca apró köztereinél jelentkeznek.

A korán betelepülő vallási közösségekből is csak egy-egy köztérnév jelzi a korábbi szerzetesi birtokokat. A pálosok esetében a Papnövelde utca, a ferenceseknél a Ferenciek tere, a szervitákért pedig egyértelmúen a Szervita tér szól. Ezekre számos új réteg rakódott rá, melyek köthetôk családok beköltözéshez (például a Károlyi-család), környéki funkcióváltáshoz (mint az ispotályból lett Károly-kaszárnya) vagy forradalmakhoz (leginkább 1848 emlékezete).

A Belvárosban vannak bizonyos „ósutcák”, melyek az idő haladtával feldarabolódtak vagy kibővültek. Gyakran vallási tartalommal rendelkeztek: Pauliner Gasse, Seminarium Gasse, Mönchen Platz, Serviten Gasse, Franziskaner Gasse. Viszont akadtak világi archetípusok is: Hayducken Gasse, Ketschkemeter Gasse, Herrn Gasse, Zwerch Gasse, Pastien Gasse. Futásuk sokszor nem egyezett meg mai lenyomataikkal, illetve több esetben egymástól már akkor is elkülönüló köztereket hívtak azonos néven.

Az említett kezdeti mintákat akár három-négy réteg is fedheti. A névtörténeti vizsgálatok alapján pedig látható, hogy a korai és jelen állapotok közti tematikákból is mindössze pár darab maradt folyamatosan látható, vagy lett az államszocialista réteg maradványából visszakoptatva. Míg a Belvárosban a 19. századi üzletnevek többé-kevésbé töretlenül 


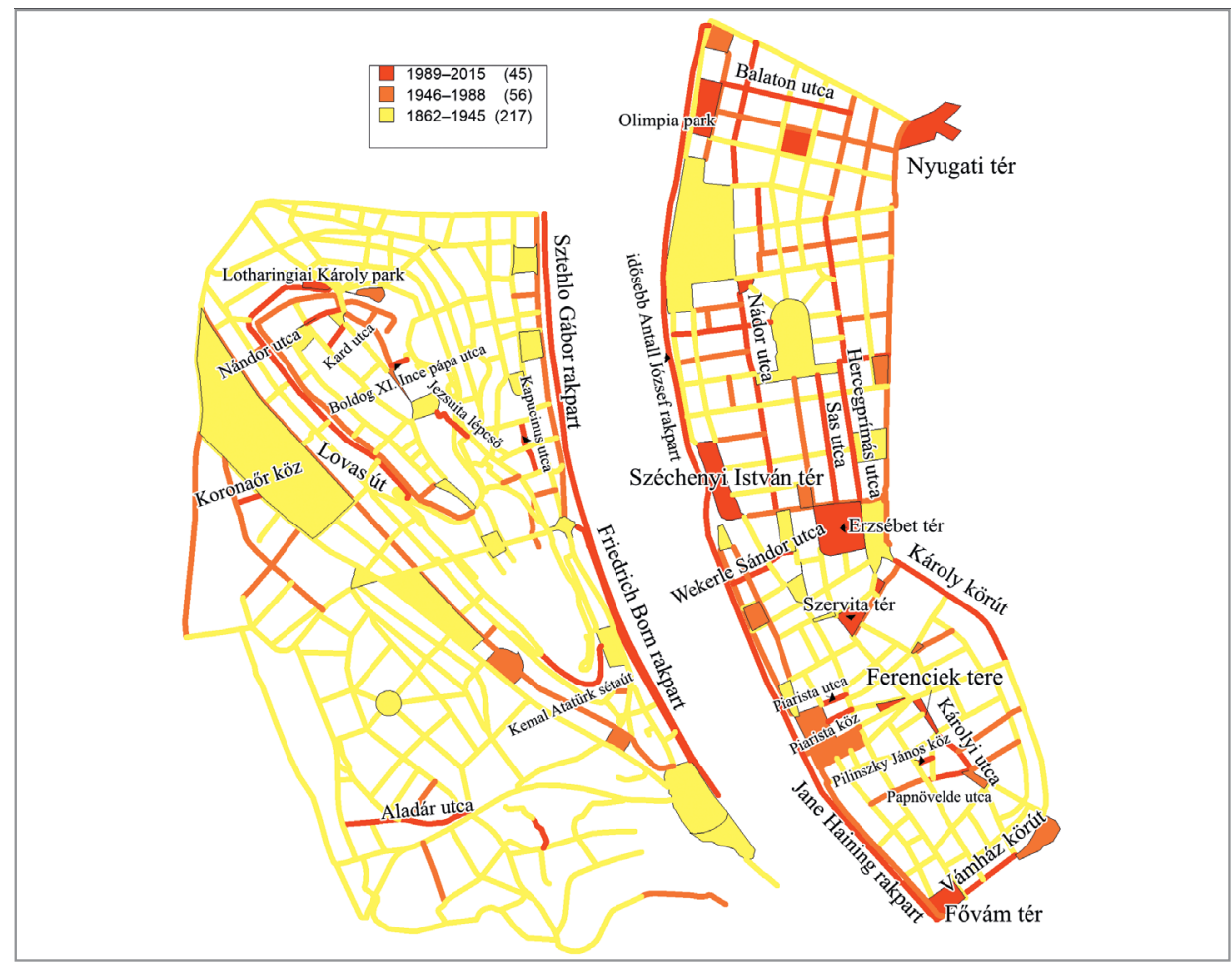

3. ábra Az I. és az V. kerület utcanév-szövetének stabilitása az utolsó névváltozás időszakának feltüntetésével és a legfrissebb elemek kiemelésével

Figure 3 Stability of the street name texture in $1^{\text {st }}$ and $5^{\text {th }}$ districts with representing the last period of name changes and highlighting the latest elements

Forrás: Saját szerkesztés RÁdAY M.-MÉSZÁros G. 2013 alapján;

Source: Author's own based on RÁDAY M.-MÉSZÁRos G. 2013

szerepelnek (Galamb, Aranykéz, Kígyó), Lipótvárosban a kereskedelmi központra való reflektálás helyett (a Sas utcát leszámítva) inkább személynevek, történelmi események vannak kiírva (Október 6., József Attila). A több saját névátírási korszakot megélt Városházakörnyék a katonai múltból mindössze a kaszárnyához kapcsolható Sütő utcát és a Károly körutat tudta megtartani. Ferenc József Lánchídhoz közeli családi névbokrát pedig mára csak az Erzsébet tér mutatja. Összességében tehát az első ránézésre tájidegennek tünő közterületnevek inkább a jelen és elmúlt korszakok domináns rétegein keresztül visszatekintő „,(archi)tektonikus ablakok” (LEFEBVRE, H. 1991 [1974]; BAROCH C.-BERKI M. 2019). Továbbá megállapítható, hogy egy új réteg kialakulásáért nem feltétlen egy egész társadalmi-politikai fordulatot megelőző, liminális szakasz felel (CZEPCZYŃSKI, M. 2008). Az invalidus ház, Károly-kaszárnya, Városháza transzformáció ugyan politikai kötődésú, de a környéki utcanevek felülírása nem az ateizmus, a militarizmus vagy a bürokrácia teret megerőszakoló intézkedése, hanem egy valamelyest organikus, a tájékozódást és a jelentésmagyarázatot is segítő fokozatos idomulás.

Az egypártrendszeri propaganda az V. kerületben többféleképpen hatott. A reprezentatív, forgalmas terek a korszak elején gyakran kaptak sztálinista nevet: Sztálin tér, Molotov tér, Dimitrov tér, Tolbuhin körút. Utóbbi kettő kihúzta a rendszerváltásig, de Sztálinból Engels, Molotovból Vigadó tér lett, már az ötvenes években mutatva a távolságtartást 
(PALONEn, E. 2008). Szerepet kaptak a magyar baloldal több generáción és ideológián átívelő képviselői, például Károlyi Mihály, Lengyel Gyula, Pálffy György vagy Münnich Ferenc. De találhatunk, találhattunk itt olyan antifasiszta, baloldali neveket, akik az előző rendszer kultuszépítése miatt tévesen lettek azonosítva a létező szocializmus búneivel: Somogyi Béla, Szende Pál, Pesti Barnabás, Stollár Béla, Ságvári Endre. A negyedik halmaz az ideológiailag nem terhelt, vallásmentes vagy Habsburg-ellenes közterekre törekedő csoport: Október 6., Egyetem, Eötvös Loránd, Apáczai Csere János. Az egyértelmúen önkényuralmi rendszert kiszolgáló neveket már rögtön a rendszerváltás után lecserélték. A szimplán baloldali kötődésú nevek tisztogatása azonban még a közelmúltban is esedékes volt (CZEPCZYŃSKI, M. 2008).

Az V. kerület két városrésze a jelenleg használatos köztérneveken keresztül jól kimutathatóan elkülönül (2. és 3. ábra). Néhány ósi, fennmaradt utcanév csak a Belváros korai történetét tárja fel. Lipótvárosban a korábbi kikötők nyomait (a mai Széchenyi István és Kossuth Lajos tér), a régi sóhivatal helyét (József nádor tér és Széchenyi István tér) vagy a régi üzletek, múhelyek nevét viszont több réteg más típusú névhalmaz fedi. Ezek a rétegek pedig már egyértelmúen a 19. század végére és a 20. századra jellemző személyi névadási gyakorlatot ôrzik (PóTó J. 2012). Ezt alátámasztja az az aránypár, miszerint a jelen közterületneveken belül Lipótvárosban a személynevek közel háromnegyedes túlsúlyban vannak, míg a Belváros utcatábláit csak kicsit több mint egyharmad részben foglalják el (4.ábra).

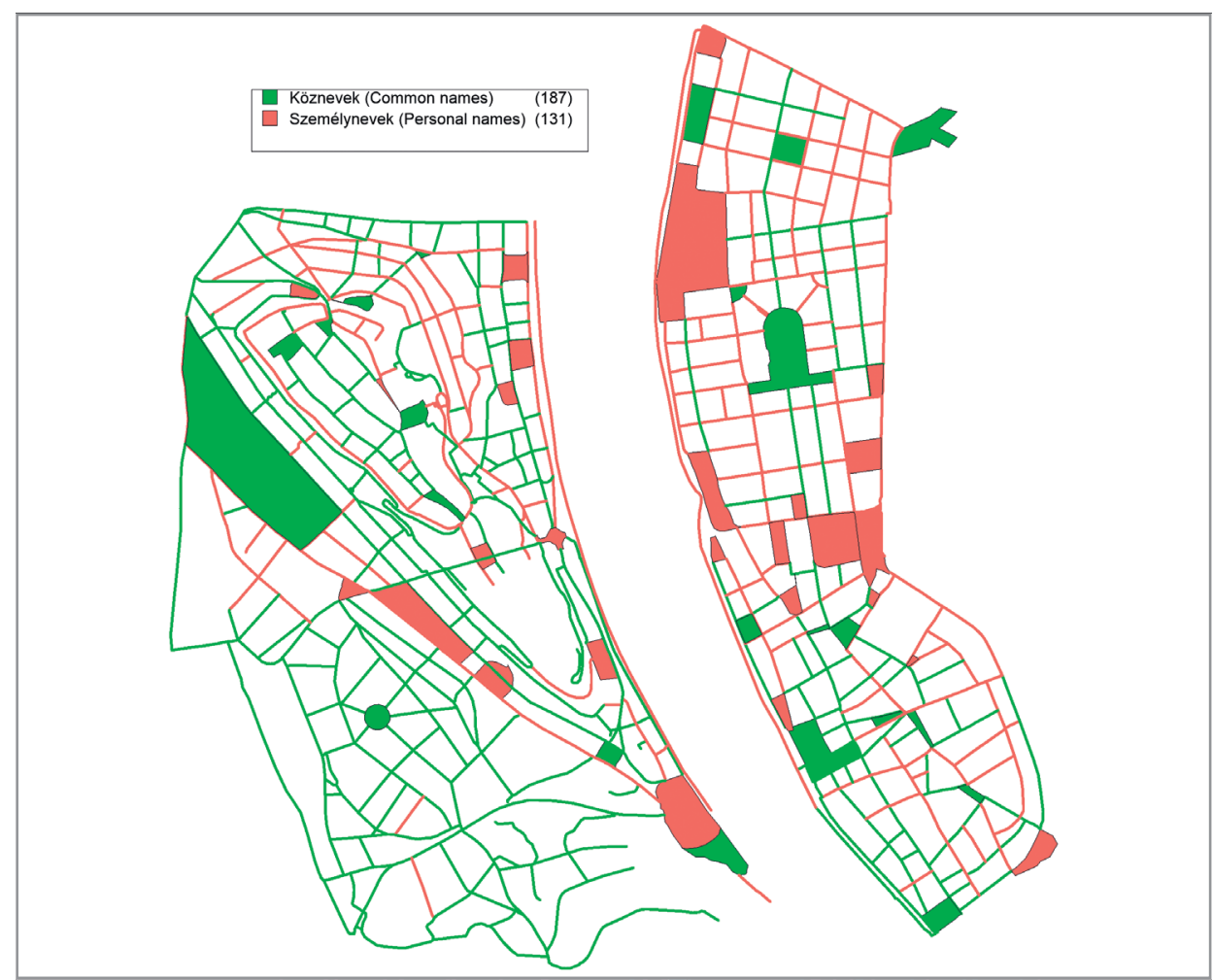

4. ábra A köz- és személynevek területi eloszlása az I. és V. kerületben

Figure 4 Territorial distribution of common and personal names within the street names of $1^{\text {st }}$ and $5^{\text {th }}$ districts

Forrás: Saját szerkesztés RÁDAY M.-MÉSZÁROs G. 2013 alapján;

Source: Author's own based on RÁDAY M.-MÉsZÁRos G. 2013 


\section{Térbeli hatalomváltás: a két kerület összehasonlítása}

A végső következtetések levonásában az elemzett két térség összehasonlítása szükségszerú (a komparativitás fontosságának kihangsúlyozását lásd AZARYAHU, M. 2011) (2., 3. és 4.ábra). A két központi kerületet elhelyezkedésük, funkciójuk és szimbolikus tereik miatt is kulturális küzdótérként vezettem be (RosE-REDWOOD, R.-ALDERMAN, D.-AzARYAHU, M. 2009). Az I. kerületet már a múlt arénájának tekinthetjük. Ahogy a létező szocializmus sem tudta igazán megvetni lábát, a rendszerváltást követő átnevezések is inkább visszakeresztelések vagy szükségtelen próbálkozások. Ez a látszólagos befejezettség az öncélú múltidézéssel valójában a liminalitás megmerevítését okozza. Nem csak eltüntet egy alternatív, antiklerikális történelmi szálat, de mesterségesen hoz létre történelmi kapcsokat (Kemal Atatürk sétaút, Lotharingiai Károly park) és ír felül köznévként interpretálható, lokálisan kifejlődött utcaneveket (lásd Ibolya utcából lett Boldog XI. Ince pápa utca). A Vár és vonzáskörzete történelmi gyökereinél fogva komoly jelképes tartalommal bír, de a 20. század folyamán végleg elvesztette valódi hatalmi súlyát, melyet napjainkban erőltetett politikai gesztusokkal próbálnak visszaadni. Utcaneveiben a török kortól a dualizmus hanyatlásáig tartó Budát konzerválja, számottevő középkori visszautalással (például Hunyadi-féle köztérnevek, Szent György tér és utca), valamint néhány elemben felvillantva a 20. század eseményeit (rakpartok, Szabó Ilonka utca). Az V. kerület azonban a jelen küzdőtere, a környező kerületekkel való folyamatos formálódása pedig a továbbra is tartó, elhúzódni látszó explicit liminális szakaszt jelzi (CZEPCZYŃSKI, M. 2008). Az utcanevek itt fokozottabban reagálnak a 19-20. századi hatalmi fordulatokra. Abból, hogy a szocialista vezetés is forró pontként tekintett a két városrész utcáinak szimbolikájára, egyenesen következik, hogy a rendszerváltást követó liminális kormányok is a saját képükre akarták és akarják formálni a városrészek szövegét.

Az I. kerületre jellemző a szakadozott vagy alig fellelhető utcanév-mintázatok elterjedése. A Tabán hosszanti völgyében az egykori utcanévhálózatban kirajzolódik a spontán vagy motivált névadás korát idéző tematika néhány tipikus válfaja: birtokosok, vendéglők, múhelyek, természeti formák (BIRK Z. 1996; T. SOMOGYi M. 2005). Ezzel szemben az V. kerület több idősík és réteg mentén felosztott mintái sokszor első ránézésre is felfedezhetôk. A városrészi megosztottság egyszerű időbeli eltérésen alapul: Belváros a várfallal körülvett mag, Lipótváros a később hozzáépült, modernebb településképú gyárnegyedből lett hivatali-politikai központ (1.ábra). A kerületen belüli megosztottság így csak a történeti gyökereken múlik, a szocialista és a rendszerváltás utáni intézkedések már egységesen kezelik őket. Nem mellékesen a pesti belváros dinamizálását fokozta, hogy itt hamarabb indult meg a német nevek magyarosítása, míg a budai oldal tovább maradt a németajkúak hatása alatt. Ez a mai napig fellelhető számos budai kerület út-utca rangbéli képzavarában. Így az V. kerület személynévi szimbolizmusának előretörése egyben az I. kerületi alkony is (3. ábra). Alátámasztásként megállapítható, hogy jelenleg az egész I. kerületben kevesebb személy nevét viselő közterület van, mint Lipótvárosban (4. ábra), mutatva a lassanként áthelyeződő, centralizált városképet (AZARYAHU, M. 1996).

Érdekes vizsgálati pont a magánbirtokok feldarabolása. Az I. kerület beépítetlenebb, fallal nem határolt részén (Gellérthegy, Naphegy, Tabán) olyan családok birtokainak nevei őrződnek, melyekról lényegi információnk kevés van. Ezzel szemben a Belváros várfali keretek közé szorított birtokait felőrölte az V. kerület központivá válása. A pálosok, ferencesek, szerviták területeit központi funkciók váltották le, így egy-egy köztérnévbe szorultak vissza.

A nemzetiségi nevek közt is találunk különbséget, bár csoportjaik jelentősen megfogyatkoztak. A Várnál minden utcanévből kikerültek (Sváb, Zsidó, Francia, Olasz), de a Tabán 
lebontásával a Görög utca is megszúnt. Ezzel szemben a szerb kisebbség a Belvárosban képviselteti magát (Vitkovics Mihály utca, Szerb utca), holott történelmi központjuk a Ráczváros, vagyis a Tabán volt (SchmaLL L. 1906). Lipótváros pedig Bihari János személyével a cigányságot is felteszi a térképre.

Mindkét kerület esetén beigazolódik, hogy a történelmi városrészek jelenkori létezése nem véletlen, és hogy a különböző egységeknek vannak történeti főszereplőik, akik akár az utcatáblákról köszönnek vissza. A Gellérthegy és Krisztinaváros egyes részei időtlenségükbe burkolódzva fenntartják az ismeretlen földbirtokosokat, míg a Tabán maradványa Döbrentei Gábor nevével jelzi a hajdani pezsgő kultúra húlt helyét. A Vár szúkös terei a török ellen harcoló hősök és a nyugati kereszténység hú szolgálóinak szimbolikus vidéke, itt-ott kiegészülve a dicső középkorral és néhány koramodern magyar ikonnal. A Víziváros pedig történelmi funkciójához illően, amolyan pufferzónaként viselkedik.

A Belváros a régi és a modern kulturális életet is megtestesíti, akár a Képíró (Schöfflcsalád) utcán, akár a Pilinszky János közön keresztül vizsgáljuk. Politikai szereplőiben a márciusi forradalmárokat (Petőfi, Kossuth, Irányi, Nyáry) és az első városvezetőket (Gerlóczy, Bárczy, Kamermayer) tisztelhetjük. Lipótváros palettája azonban mindig is a hatalmi kérdésekben volt széles: a Monarchia emlékeitől, a jobb- és baloldali törekvésekig, József nádortól Bajcsy-Zsilinszky Endrén át Stollár Béláig. Azonban rendkívül szembetûnő a baloldali hagyományok elnyomása, felülírása és eltüntetése, mely felfogható egy a liminális szakaszt erôlködve lezárni kívánó jobboldali narratívának.

\section{Az utcanevek helyzete a közelmúlt és napjaink politikai kontextusában}

NoRA, P. (1999) emlékezethelyein elindulva az utcanevek hagyatékok, melyek segítenek pozícionálni a helyi társadalmat a városon belül, vagyis identitásképző erejük van (NoRA, P. 1999). Ugyan a posztszocialista országokban kevéssé tudunk régre visszanyúlni (РóTó J. 2012; RÁDAY M. 2013), de a helynév pótolhatatlansága nemcsak annak korában rejlik. Amennyiben az épített környezet, a társadalmi dimenziók és a környező közterek nevei is megváltoznak, a tárgyalt jelentéstartalom kicsúszik a szemiotikai hálóból: értelme és megérthetôsége megszűnik eredeti kontextusa nélkül (RÁDAY M. 2013). A kommemorativitás tehát nem a legősibb archívum visszaállítása lenne, hanem egy olyan verzió, aminek a jelen társadalmával is kapcsolata van (NoRA, P. 1999). A nomenklatúra mindig is a rezsimek következménye volt, így az utcanevek axiomatikus tulajdonságai, hogy az innen nézve hitelüket vesztett rendszerek, miliők nem jelennek meg közvetlenül a város textúrájában (Azaryahu, M. 1996, Palonen, E. 2008). Azonban felmerül a regnáló politikai elit elnyomó tevékenysége, akár pártállástól függetlenül maradandót alkotó személyekről (Szende Pál, Petermann bíró) vagy egyéb semleges megnevezésekról (Köztársaság tér, Moszkva tér) van szó. Egyrészt megpróbálják saját ízlésük szerint szelektálni a történeti-kulturális memóriát, ezzel valamelyest presszionálva a mindenkori ellenállást. Másrészt elfedik a múlt mai napig vitát generáló vagy éppen elnémított korszakait is, legyen az a magyar jakobinus mozgalom vagy az őszirózsás forradalom és 1918-1919 történései (PALONEN, E. 2008).

A hovatartozás keresése és az európai reintegráció ellenére köztereink nevei kevéssé mutatnak a kontinens felé. A 2003-ban kialakított Európa utca Soroksár egy igencsak marginális részén kapott lehetőséget, távol a főváros reprezentatív helyeitôl (RÁDAY M. 2013). A Moore, C. (2013) által megidézett Enyedi Zsolt és Bojan Todosijević vélekedése szerint Magyarország politikai elitje nem megfelelő módon változott a rendszerváltást követôen. Egyrészt a piacgazdasági átállás a maga hirtelen következményeivel nosztalgikus képet fest az elmúlt korszakról, áteresztővé téve így a két politikai rendszer határát. 
Másik lehetőség, hogy a begyưrűző kapitalizmus kedvezőtlen hatásai negatív érzelmeket generálnak a Nyugat felé. A létező szocializmus bukásával sokan a politikai baloldal reprezentációit sem értik, amire rásegít a közelmúlt parlamentjének jobboldali hegemóniája és a mindenkori ellenzék korlátoltsága. Mások az Európai Unióhoz való csatlakozásban egy újabb elnyomó hatalmat vélnek felfedezni. Az így kialakuló „morális deficit” (Moore, C. 2013) szemüvegén keresztül pedig a nyugati integráció a beáramló tôke új uralmával egy kolonizáló erő fényében mutatkozik. A posztmodern, töredezett jeleket mutató, egyszerre szélsőségesen jobbra tolódó és neoliberalizálódó hazai politikai klíma ingoványos talapzata, jobb- és baloldal képzavara, valamint a pártpolitikai intézmények és a képviseleti demokrácia válságjelenségei pedig sem a múlttal megbékélni, sem az értékrendi válságon túllépve Európa rész-egészeként létezni nem engednek. Így a jelenlegi átnevezések az önigazolást, a szuverenitást, a látszólagos egyértelmúséget, a nemzetállam fetisizálását igyekeznek közvetíteni (MoORE, 2013).

\section{Összegfoglalás}

Az elméleti keretrendszer sokban hozzájárult a névadási szándékok és a mögöttes politikai folyamatok összefüggéseinek feltárásához. Mindezek alapján a mindenkori budapesti köztérelnevezések nem önmagukban álló, elszigetelt elemei a városszövetnek. Kulturális és történeti jelentőségú ok-okozati kötelékek mentén szerveződnek tematikus egységekké, melyek egymást magyarázva próbálnak irányt és helyet mutatni a fizikai térben, jelentést és identitást biztosítani a társadalmi térben, és mindezt teszik az aktuális hatalom kivetüléseiként, ezáltal a helyek/közterek maguk válnak a hatalom narratíváinak mesélőivé (Bodó J.-Biró A. Z. 2017). Élettartamuk nem abszolút és gyakran nem folytonos. Az egyes nevek hosszú évszázadok múltán válhatnak korszakuk utolsó hírnökévé, de az eltúntek idővel egy más fizikai és szemiotikai kontextusban újra előkerülhetnek, bonyolítva ezzel a tér- és időbeli mintázatok szövedékét.

A hatalmi szemszöget tekintve kirajzolódott, hogy a szimbolikus terek mozgása nemcsak egy-egy közterület esetén érhető tetten, hanem városrészi vagy kerületi térszervezési szinten is (ERőss Á. 2016). Az I. kerület jelentős része megragadt egy jóval korábbi döntéshozó szemlélet elgondolásában. Az V. kerület viszont hosszú idő óta az átnevezések forró pontjává vált, átvéve a Várnegyed allegorikus szerepkörét. Az utcanévhálózat mintázatai megmerevedhettek vagy újabb réteggel fedték le ôket, illetve nem egyszer egy korábbi állapotig erodálódtak vissza. Az ehhez szükséges eszköz pedig a kulturális amnézia és a tájképi tisztogatás gyakorlatában nyilvánul(t) meg (RoSE-REDWOOD, R.-ALDERMAN, D.-AZARYAHU, M. 2009; CZEPCZYŃSKI, M. 2008). A módszer két legnagyobb felhasználójává az államszocialista egypártrendszer és a rendszerváltást követő kormányok váltak. A több korszakon átívelő, erós jelképiséggel bíró közterületeknek hasonló volumenú neveket adtak a saját eszmerendszerük értelmezési tartományában. Ahogy korábban a legmagasabb hatalmi tisztséget betöltő, leggazdagabb emberek a közterületek fókuszpontjaiban laktak, úgy a köztéri hatalmi szimbolizmus ma ugyanilyen forgalmú szerkezeti helyeket szemel ki a névadás céljából (VöRÖs K. 1979; FouCAULT, M. 2000 [1967]). A tapasztalat azt mutatja, hogy sok tekintetben a máig elhúzódó, a rendszerváltáskor kezdődó átnevezések sokkal erőteljesebben tisztogatnak, mint a korábbi önkényuralom, így továbbra is a múlt szubjektív legitimálása folyik (NoRA, P. 1999).

Úgy gondolom, az utca át- és elnevezések kérdésköre, esetleges autonóm mintázatok kutatása csupán a közproblémák felszínét jelentik. Akik azonban kritikával szemlélik a fizikai, földrajzi és társadalmi valóságot és a hatalom által folyamatosan és szorosan 
mellé teremtett illúziót, fontos előrejelzésekre, rendszerhibákra és intő jelekre lelhetnek az utcanévtáblák alakulásában vagy az utcanevek tematikus términtázataiban. Így észlelhetik vagy éppen ezek ellenében múvelhetik a posztliminális Budapest szükségszerúen alternatív, rizomatikus kezdeményeit (DELEuzE, G.-GUATTARI, F. 2005 [1987]; CzEPCZYŃSKI, M. 2008), ha már a hivatalos városszöveghez továbbra is rendkívül korlátoltan szólhatnak hozzá. Ugyanis a városszöveg narratívájának írói még mindig a történelem eróltetett, prezentista feltámasztásán dolgoznak, ami „... a jövőre irányított jelen szemszögéból szabályozza a múlt perspektíváinak fényéit és árnyait.” (NORA, P. 1999, p. 123.).

\section{BAROCH CSABA \\ ELTE TTK Társadalom és Gazdaságföldrajzi Tanszék, Budapest baroch.08@gmail.com}

\section{IRODALOM}

AugÉ, M. 1995 (1992): Non-Palces. Introduction to an Anthropology of Supermodernity. - Verso, London-New York. 130 p.

Azaryahu, M. 1996: The Power of Commemorative Street Names. - Environment and Planning D: Society and Space 14. pp. 311-330.

Azaryahu, M. 2011: The Critical Turn and Beyond: The Case of Commemorative Street Naming. - ACME 10. 1. pp. 28-33.

BARoch C.-Berki M. 2019: Lwów, Lemberg, Lvov, Lviv - Az „oroszlánok városa” mint palimpszeszt. - In: KôSZEGI et al. (szerk.): Etnikai földrajzi kutatások a posztszovjet térségben. Eötvös Loránd Tudományegyetem, Természettudományi Kar, Budapest. pp. 191-210.

Barthes, R. 1967: Denotation and Connotation. - In: Barthes, R.: Elements of Semiology. Hill \& Wang, New York. pp. 89-98.

BAUKO J. 2015: Kétnyelvűség és névszemiotikai tájkép. Kisebbségi névtörvények és vizuális tulajdonnév-használat Szlovákiában. - Névtani Értesítő 37. pp. 179-194.

Bнавна, H. K. 1994: The Location of Culture. - Routledge, London-New York. 285 p.

BIRK Z. 1996: Az utcanevek és változásaik társadalmi jelentése. - Jel-Kép 4. pp. 55-68.

Bodó J.-BiRó A. Z. 2017: Szimbolikus térhasználat változó szerepben. - Replika 105. 5. pp. 147-161.

CZEPCZYŃski, M. 2008: Cultural Landscapes of Post-Socialist Cities: Representation of Powers and Needs. - Ashgate, Aldershot. 224 p.

Deleuze, G.-Guattari, F. 2005 (1987): A Thousand Plateaus: Capitalism and Schizophrenia. - University of Minnesota Press, Minneapolis. 610 p.

DERRIDA J. 1997 (1967): Of Grammatology. - John Hopkins University Press, Baltimore. 456 p.

ERŐss Á. 2016: Holidays and Sapces: Episodes from the Life of Symbolic Spaces of Beregszász. - In: BERGHAUER S. et al. (eds.): Social Geographical Challenges, and Search for Adequate Answers in East-Central Europe of the $21^{\text {st }}$ century. II. Rákóczi Ferenc Kárpátaljai Magyar Főiskola, Beregszász. pp. 97-103.

ERôss Á. 2018: Szimbolikus terek és térhasználat többnemzetiségú városokban: Beregszász és Nagyvárad példája. Doktori disszertáció. - Eötvös Loránd Tudományegyetem, Földtudományi Doktori Iskola, Budapest. 158 p.

Foucault, M. 1990 (1975): Felügyelet és büntetés. A börtön története. - Gondolat, Budapest. 424 p.

FouCAULT, M. 2000 (1967): Eltérő terekről. - In: FouCAUlT, M.: Nyelv a végtelenhez. Tanulmányok, előadások, beszélgetések. Latin Betûk, Debrecen. pp. 147-155.

Gyáni G. 2016: A történelem mint emlék(mú). - Kalligram, Budapest. 153 p.

Jung, C. G. 1972: Synchronicity: An Acausal Connecting Principle. - In: JunG, C. G.: Collected Works of C. G. Jung, Vol. 8. (2 ${ }^{\text {nd }}$ Edition). Princeton University Press, Princeton. pp. 417-420.

Kadmon, N. 2004: Toponymy and Geopolitics: The Political Use - and Misuse - of Geographical Names. The Cartographic Journal 41. 2. pp. 85-87.

Kaups, M. 1966: Finnish Place Names in Minnesota: A Study in Culrural Transfer. - Geographical Review 56. 3. pp. 377-397.

Lefebvre, H. 1991 (1974): The Production of Space. - Blackwell, Oxford. 454 p.

McDAVID, R. I. 1958: Linguistic Geographic and Toponymic Research. - Names: A Journal of Onomastics 6. 2. pp. $65-73$. 
Moore, C. 2013: The Renaming of Public Space in Budapest: The Divided Politics of Contemporary Hungarian Identity. - Portal on Central Eastern and Balkan Europe 36.

N. KovÁcs T. 2007: Helyek, kultúrák, szövegek: a kulturális idegenség reprezentációjáról. - Csokonai, Debrecen. $172 \mathrm{p}$.

NORA, P. 1999: Emlékezet és történelem között. A helyek problematikája. - AETAS - Történettudományi folyóirat 3. pp. 116-128.

NorA, P. 2007: Emlékezetdömping (Az emlékezés hasznáról és káráról és hasznáról). - Magyar Lettre International 66. pp. 35-37.

Palonen, E. 2008: The City-Text in Post-Communist Budapest: Street Names, Memorials, and the Politics of Commemoration. - GeoJournal 73. pp. 219-230.

PóTó J. 2012: Terek és nevek. Köztérelnevezések a szimbolikus politika tévútjain - Történelmi Szemle 2.1. pp. 161-173.

RÁDAY M. (szerk.) 2013: Budapesti utcanevek A-Z. - Corvina Kiadó, Budapest. 755 p.

Rose-Redwood, R.-Alderman, D.-Azaryahu, M. 2009: Geographies of Toponymic Inscription: New Directions in Critical Place-Name Studies. - Progress in Human Geography 34. 4. pp. 453-470.

Schmall L. 1906: Buda-Pest utczái és terei. Adatok a buda-pesti utczák és terek elnevezéséhez és történetéhez. - Budapest Székesfőváros Házinyomdája, Budapest. 193 p.

Storey, D. 2011: Critical Toponymies. The Contested Politics of Place Naming. - European Planning Studies 19. 6. pp. 1131-1132.

T. SomogYi M. 2005: Budapesti utcanévváltozások 1989 után. Kézirat.

VÖRÖS K. 1979: Budapest legnagyobb adófizetői: 1873-1917. - Akadémiai Kiadó, Budapest. 186 p.

YeOH B. 1992: Street Names in Colonial Singapore. - Geographical Review 82. 3. pp. 313-322. 